Az ENSZ és a Nemzetközi Távközlési Unió az információs társadalommal foglalkozó világ-csúcstalálkozó (World Summit on the Information Society WSIS) létrehozásával hozzájárult az „információs társadalommal” kapcsolatban jelenleg folyó diskurzushoz. Ez a tanulmány azt elemzi, hogy a WSIS mit ad hozzá ehhez, különös tekintettel arra, hogy a csúcstalálkozó milyen „víziót” tett magáévá az információs társadalomról és a globális „digitális szakadékról”. A tanulmány módszere a WSIS két fő dokumentuma, az Elvi Nyilatkozat és a Cselekvési Terv átfogó, kritikai tartalomelemzése. A tartalomelemzés felhasználja a diskurzus-analízis és az ideológiai kritika módszerét, kvantitatív és kvalitatív eljárásokat alkalmazva. Az elemzés eredménye azt mutatja, hogy a WSIS teljesen utópisztikus technikai determinista képet fest az „információs társadalomról”, amely túlegyszerüsíti és általánosítja ezt a komplex jelenséget, amelyről egyelőre nem alakult ki konszenzus.

Így hivatkozzon erre a cikkre:

Pyati, Ajit K.. „WSIS: Kinek a víziója az információs társadalomról?”. 
Ajit K. Pyati

\section{WSIS: Kinek a víziója \\ az információs társadalomról?}

\section{Bevezetés}

Az információs és kommunikációs technológia (IKT) növekvő fontossága az emberi társadalmakban kétségkívül egyike mai világunk meghatározó vonásainak. Az IKT beépült az emberi szerveződési törekvések valamennyi szintjébe, és nagy hatást gyakorol mindazokra a módokra, ahogyan az emberek kommunikálnak. Az IKT területén történt újítások óriási átalakító erejének legnyilvánvalóbb új példája az internet és a világháló (World Wide Web) fejlődése az elmúlt évtized során.

Az a kiemelkedő szerep, amit az információ a mai társadalomban játszik, különbözố tudósokat és vezetóket arra késztetett, hogy kijelentsék: ma újfajta társadalomban, az úgynevezett ,információs társadalomban” élünk, ahol a társadalmi szerveződés új módozataiban az információ dominál. Az „új társadalom” kialakulása azonban semmi esetre sem deklarálható viták nélkül. Az információs társadalomba való átmenetet egyesek a „folyamatosság”, mások a „szakadás” kontextusában értelmezik (Schement és Lievrouw, 1986). Más szóval, az információs társadalom fogalmának értelmezése terén vita folyik arról, hogy az információs társadalom vajon a társadalmi szervezôdés alapvetốen új formája-e, vagy csupán a társadalmi szerveződés korábbi módozatainak a folytatása. A „folyamatosság vagy szakadás” kérdéséról folyó vita, ami Frank Webster munkásságában tovább artikulálódik, kétségkívül fontos. Fontossága abból a tényból következik, hogy ez a vita az információs társadalom fogalmáról folyó kritikai diskurzus egészen új területét nyitja meg.

$\mathrm{Az}$ információs társadalom létrejöttére vonatkozó gondolkodásban azonban nem egyszerú feladat a fogalmak pontos meghatározása. Igen nagy értelmezési különbségek léteznek az egyes táborokon belül is, mivel az egyes teoretikusok különböző fontosságot tulajdonítanak az információs technológiáknak és tevékenységeknek a modern világ kiformálásában. A társadalom fokozódó „informatizálódását” az elméleti szakemberek olyan különbözô tudományágak felól közelítik meg, mint például a gazdaságtudomány, a szociológia és a kommunikációelmélet, amelyek befolyásolják a társadalmi átalakulással kapcsolatban kialakított állásfoglalásukat. Webster (2002) részletesen feldolgozta az információs társadalom különbözô elméletei között mutatkozó eltéréseket, rámutatva két tábor kialakulására: az „információs társadalom” mint új társadalomtípus eszméjének a hívei elkülönülnek azoktól, akik az informatizálódást a már korábban létrejött viszonyok folytatódásának tekintik. A társadalom új formáját hirdető fóbb elméleti iskolák közé tartoznak a posztindusztrializmus és a posztmodernizmus irányzatai, továbbá a „rugalmas specializálódás” folyamatait és „a fejlődés információs módját” kutató múhelyek (Webster, 2002). A vitázó felek másik táborában, amely a már korábban kialakult viszonyok folyamatos átalakulását hangsúlyozza, a neomarxizmus, a rugalmas felhalmozás, a reflexív modernizáció és a közszféra elméletei találhatók (Webster, 2002). Mindezek az elméletek együttesen adják a mai világban végbemenó információs forradalom megértésének kontextusát. 
Mindazonáltal, akár valóban új információs társadalomban élünk, akár nem, az kétségtelen tény, hogy az IKT és az információval összefüggố munka kiemelkedô szerepet játszik a társadalmi átalakulásokban. Az „információs társadalom” fejlesztésébe és az arról folyó vitába az említett társadalomtudósokon kívül bekapcsolódtak a világ kormányai és olyan nemzetközi szervezetek is, mint például az ENSZ és az Európai Unió. Az EU több éve magáévá tette az információs társadalom eszméjét. 2000-ben például az EU - a „lisszaboni stratégia” jegyében - olyan fejlesztési célokat fogalmazott meg tagországai számára, amelyek magukban foglalják „a felkészülést - az információs társadalom létrehozását, valamint a kutatást és fejlesztést elősegítő jobb politikai stratégiák kidolgozása útján - a tudásalapú gazdasághoz és társadalomhoz vezetố átmenetre" (Bogdanowicz és mtsai, 2003). „Az információs társadalom felépítése az EU számára közvetlenül összefügg azzal, hogy az IKT-eszközök hozzáférhetók és elérhetók legyenek az egyének, a szervezetek és az egész társadalom számára" (Bogdanowicz és mtsai, 2003). Az EU figyelmének középpontjában az IKT és az eszközök összekötöttségét szolgáló infrastruktúra fejlesztése áll. Az EU az információs társadalomról folyó vitákat az infrastruktúra kibớvítésével, valamint a tagállamok egységével és kohéziójával szorosan összefüggó stratégiai kérdésnek tekinti (Lievrouw és mtsai, 2000).

Az ENSZ az UNESCO égisze alatt már több évtizede foglalkozik az információs társadalom fogalmával, különös tekintettel a MacBride Bizottság 1980. évi jelentésére. Az UNESCO által a kommunikációs problémák tanulmányozására létrehozott és szponzorált nemzetközi bizottság (röviden: MacBride Bizottság) 1980-ban tette közzé jelentését „Sok hang, egyetlen világ: kommunikáció és társadalom, ma és holnap” (Many voices, one world: Communication and society, today and tomorrow) címmel. A jelentés különféle témákkal foglalkozik, köztük olyan kérdésekkel, mint a cenzúra, a média tulajdonviszonyainak koncentrálódása, továbbá a sajtó szabadsága és felelőssége, hogy csak egy néhányat említsünk. Az UNESCO mint szponzoráló ügynökség úgy döntött, hogy nem az „információra” koncentrálja a figyelmét, hanem inkább a „kommunikációt” mint alapvető jogot hangsúlyozza.

Az ENSZ egy másik kísérlete az információs és kommunikációs kérdések fontosságának kidomborítására az információs társadalommal foglalkozó világ-csúcstalálkozó (World Summit on the Information Society, WSIS) megszervezése. A WSIS az információs társadalomról az EU által vallott felfogás elterjesztésére és elfogadtatására irányuló kezdeményezésnek tekinthető, mivel a találkozó programja az IKT-re és az infrastruktúra bốvítésére koncentrál, s ezt az eszmei alapállást kiterjeszti a nagyobb „világközösségre”. Ez a csúcstalálkozó, amelyet az ENSZ a Nemzetközi Távközlési Unióval (International Telecommunication Union, ITU) közösen finanszíroz, két fázisban bonyolódik le. Az első fázisra Genfben került sor 2003 decemberében, a második fázis helyszíne pedig Tunisz lesz 2005 novemberében. A csúcstalálkozón részt vevő csoportok között különféle kormányok tagjait, a gazdasági élet szereplôit és a civil társadalom képviselóit találjuk. A csúcstalálkozó elsô fázisában kibocsátották az „információs társadalom” Elvi nyilatkozatát (Declaration of Principles) és Cselekvési tervét (Plan of Action), amelyek az ENSZ által szponzorált konferenciák standard dokumentumaivá váltak. A WSIS az információs társadalom kérdéseiról tovább folytatódó viták sorába illeszkedik és az ENSZ-csúcstalálkozók modellstruktúráját követi, amit a hidegháború utáni jelenségként elôször 1992-ben léptettek életbe, a Rio de Janeiróban tartott Föld Csúcstalálkozó (Earth 
Summit) alkalmából. A csúcstalálkozó második fázisára 2005 novemberében Tunéziában kerül sor, ahol a remények szerint további haladás fog történni az első fázisban kitúzött célok elérése és az utómunkálatok terén. A WSIS az elsô olyan ENSZ-csúcstalálkozó, amely két fázisban bonyolódik le.

A WSIS esetében a csúcstalálkozó megszervezésében az ITU vállalta a vezetô szerepet, és elsődleges fontosságú tényezóként a „kommunikáció” helyett az „információt” emelte ki. Így tehát a WSIS mintegy a nemzetközi közösség figyelmének áthelyeződéseként fogható fel, melynek eredményeként a „kommunikáció” helyett az „informáciô" kerül a figyelem középpontjába. A WSIS nagyszabású és a korábbiaknál jóval ambiciózusabb projekt, és ez az elsó nagyobb ilyenfajta csúcstalálkozó, amely kizárólag az információ kérdéseivel foglalkozik.

Az IKT-vel összefüggó kérdések szabályozása terén jelenleg az ITU a legátfogóbb nemzetközi fórum, melynek tagjai közé tartoznak a Nemzetközi Távközlési Unióhoz csatlakozott országok kormányai, továbbá a magánszektor és a civil társadalom szervezetei is (MacLean, 2003). Az ITU-nak van a legszélesebb körú szabályozási funkciója a nemzetközi szervezetek között, beleértve a múholdak orbitális pozíciójának és a rádiófrekvencia-spektrumnak a szabályozását is (MacLean, 2003). A nemzetközi szabályozásra vonatkozó elvi-elméleti keretek között az ITU igen sikeres nemzetközi távközlési rendszerek kialakításának a bázisául is szolgált (Cogburn, 2003). Ez a rendszer segített kidolgozni a távközlés ,játékszabályait”, valamint a kollektív döntéshozatalra és a szabályok betartatására szolgáló mechanizmusokat (Cogburn, 2003). Az ITU hajlandósága a WSIS finanszírozására esélyt ad számára, hogy befolyásolni tudja a vitát az IKT-eszközökkel és azok fejlesztésével kapcsolatos kérdések szélesebb körében is. A világban folyó átalakulás - a globalizációval és az „információs kor” beköszöntésével kapcsolatos problémák növekvố tudatosodása jegyében - kihívást jelent az ITU rendszere számára, mivel már folyamatban van a legújabb átmenet a globális információs infrastruktúra és globális információs társadalom (Global Information Infrastructure/Global Information Society, GII/GIS) rendszerének kialakulása felé (Cogburn, 2003). Úgy túnik, hogy az ITU - az új információs rendszer meghatározása érdekében folyamatosan kifejtett erófeszítéseinek részeként - arra használja fel a WSIS-t, hogy továbbra is fontos szerepet biztosítson magának a gyorsan globalizálódó és információval telítődố világban.

Az ENSZ a segítô szándékú közremúködő szerepét játssza az „emberközpontú, mindenkit magában foglaló és fejlôdésre orientált információs társadalom" létrehozásában (Declaration of Principles, 2003). A csúcstalálkozó elvi állásfoglalása szerint az információs technológiát az emberi és társadalmi fejlódés továbbvitelének, valamint az ENSZ millenniumi céljainak a szolgálatába kell állítani. Az ENSZ és az ITU - azáltal, hogy finanszírozzák ezt a csúcstalálkozót - mintegy tudomásul veszik és elismerik, hogy jelenleg létezik egyfajta új információs társadalom. Ebben a tanulmányban azt elemezzük, hogy az „,információs társadalom” fogalma, ahogyan ezek a szervezetek értelmezik, hogyan illeszkedik a korábban vizsgált elméleti keretekbe.

E tanulmány az információs társadalom meghatározásáról és a digitális megosztottságról a WSIS alkalmából folytatott vitákkal foglalkozik, amelyek az információs társadalomról évtizedek óta folyó viták részét képezik. Ismerteti és elemzi a WSIS fố dokumentumait, az Elvi nyilatkozatot és a Cselekvési tervet. Most, hogy a WSIS elsố fázisa véget ért és küszöbön áll a második fázis, döntô fontosságú, hogy a csúcstalálkozó 
nyilatkozatait és terveit megfelelố kritikai megvilágításban értékelhessük. A WSIS-t kritikai-elméleti megközelítésben kell vizsgálnunk, hogy olyan eseményként értelmezhessük, amely formálja mind magát az ,információs társadalmat”, mind pedig azt az új paradigmát, ami az IKT-t a fejlődő világ problémáit enyhítő eszközrendszerként definiálja. Elemeznünk kell, hogy a WSIS hogyan határozza meg a kialakuló „,információs társadalmat", és milyen terveket dolgoz ki a fejlődő országok lakossága számára a digitális megosztottság és információhoz való hozzáférés terén jelentkezó problémák kezelésére. A csúcstalálkozót megfelelő társadalmi-politikai kontextusba kell helyezni, mivel a globalizáció folyamatai az egész világon átalakítják a gazdasági és társadalmi állapotokat. Ahhoz, hogy a WSIS-hez hasonló ENSZ-csúcstalálkozók valóban fontos szerepet töltsenek be, céljaikat és feltételezéseiket szigorúan meg kell vizsgálni, és nézôpontjaik elemzésével segíteni kell, hogy megalapozottá válhassanak és a megvalósítható és elérhetố célok körébe sorolhatók legyenek. Ez az elốtanulmány a kritikai elemzés folyamatának kezdetét jelenti és segíthet kidolgozni a kutatás további irányait a globális digitális megosztottság elleni küzdelem, valamint a nemzetközi információs fejlesztési politika stratégiájának meghatározásához.

Az alábbi előtanulmány azonban részét képezi egy jóval nagyobb, folyamatban lévő programnak is. Ez a nagyobb program arra irányul, hogy a WSIS-t elhelyezze az információs társadalomról jelenleg folyó vitákban, és további kritikai elemzés alá vesse az „információs társadalom” diskurzusait és ideológiáit. Az átfogóbb vizsgálat magában fogja foglalni az információs társadalommal kapcsolatos vita kritikai megközelítéseit, kiegészítéseket ad a téma kritikai diskurzusához és megkérdójelezi azt a módot, ahogyan az ENSZ összekapcsolja az ,információs társadalom” és a „fejlődés” fogalmait. A kritikai megközelítés utat fog nyitni az információs társadalom teljesebb egyenjogúságot feltételező felfogásai elốtt és vizsgálat tárgyává teszi az ilyen fajta „társadalom” megnevezésének jelentôségét. Ez a nagyobb program többek között a domináns „univerzalista" diskurzusok megkérdôjelezésére fog koncentrálni és szóba jöhetô alternatív lehetốségeket vázol fel, amelyek kétségbe vonják a felülról kezdeményezett „víziókat".

\section{A kutatás kérdései}

E tanulmány tárgyát az információs társadalommal foglalkozó világ-csúcstalálkozó és annak a globális digitális megosztottság problémáinak kezelésére kiható következményei képezik. Az elemzés két kérdés vizsgálatára koncentrál: 1 . A WSIS mint az „információs társadalomról” folyó vitákat befolyásoló és a globális digitális megosztottság problémáinak kezelését célzó tennivalókat meghatározó esemény jelentôségének interpretációja; és 2. azoknak a szempontoknak, javaslatoknak és megoldásoknak a beható vizsgálata, amelyeket a WSIS a fő dokumentumaiban meghatároz. Az alábbi kutatási kérdések erre a két fớ témára vonatkoznak:

1. Hogyan értelmezi a WSIS az „információs társadalom” fogalmát? Milyen keretek közé helyezi a WSIS az ,információs társadalomról” szóló vitát?

2. Hogyan fogja fel a WSIS a globális digitális megosztottság problémáját? 
3. Milyen jellegú cselekvési és gyakorlati végrehajtási teendók fogalmazódnak meg (az információs társadalommal és a digitális megosztottsággal kapcsolatban) a WSIS-dokumentumokban?

4. Milyen mértékú technológiai determinizmus nyilvánul meg azokban a megoldásokban, amelyeket a WSIS javasol?

\section{A vizsgálati módszer}

E tanulmány módszere a széles merítésû, átfogó kritikai tartalomelemzés. A tartalomelemzés felöleli a kritikai diskurzuselemzést, az ideológia kritikai vizsgálatát és a politikai szemiotikai elemzést. Mind kvalitatív, mind kvantitatív eljárásokat alkalmaz. Az elemzés fó tárgyát képezô dokumentumok a WSIS által elfogadott Elvi nyilatkozat (Declaration of Principles) és Cselekvési terv (Plan of Action), amelyeket a csúcstalálkozó elsố fázisában, 2003 decemberében dolgoztak ki Genfben. Ezek a dokumentumok voltak a csúcstalálkozó fóbb eredményei, mivel ezeknek a célja az információ és a nemzetközi fejlődés összekapcsolásán alapuló feladatterv felállítása. A dokumentumok szerzói a részt vevő országok kormányainak képviselói. A dokumentumok megfogalmazása a csúcstalálkozó genfi értekezlete elótt lezajlott elókészítố üléseken történt. A civil társadalmi szervezetek bizonyos mértékig lehetôséget kaptak a dokumentumok nyelvezetének befolyásolására; például a könyvtári egyesületek nemzetközi szövetsége (International Federation of Library Associations - IFLA) és más nem kormányzati szervezetek (non-governmental organizations, NGO) lobbitevékenységet folytattak egy olyan nyelvezet kialakítása érdekében, amely a dokumentumokban tükrözi a könyvtárak, archívumok és múzeumok fontosságát (Shimmon, 2004). A dokumentumok végleges formába öntésekor azonban a végsố szó a kormányok hivatalos képviselóié volt. Ez a tény fontos lesz a dokumentumokban foglalt javaslatok és elvek elemzésekor, mivel vitatható, hogy ezek az elvek mennyire lehetnek „univerzálisak”, ha fố szerzóik kormányok képviselôi.

A kritikai diskurzuselemzés középpontjában az áll, hogy a dokumentumok hogyan befolyásolják az „információs társadalom” és a „digitális megosztottság” fogalmainak értelmezését. A diskurzuselemzés azokra a nyelvpolitikai elméletekre támaszkodik, amelyeket elsôsorban Herbert Marcuse és George Orwell fogalmazott meg. Marcuse az „orwelli nyelvezet” kifejezést a kortárs posztindusztriális társadalmakon belül érvényesülő domináns diskurzusok szerepének és jellemzố vonásainak leírására használja (Kellner, 1990). Marcuse elemzése különösen fontos e tanulmány szempontjából, mivel Marcuse szerint a nyelv úgy befolyásolja a közgondolkodást és a nyilvános diskurzust, hogy egyszersmind akadályozza a kritikai gondolkodást és vitákat (Kellner, 1990). Ezt a hermeneutikai nézópontot használjuk fel a WSIS-dokumentumok nyelvhasználatának elemzésére, különösen abban a tekintetben, hogy azok hogyan határozzák meg az „,információs társadalom” és a „digitális megosztottság” fogalmait. Érdemes megjegyezni továbbá, hogy a jelen elemzés szerzójének felfogása szerint a fogalmak meghatározása - és általában a dokumentumok nyelvezete - szándékosan pontatlan és határozatlan, s így többféleképpen értelmezhető, különféle okokból. Az értelmezés többféle lehetôsége elsôssorban éppen azért marad nyitva, hogy az értelmezést illetóen a 
csúsztatások és az egymástól eltérő olvasatok széles skáláját tegye lehetővé. Ennélfogva az elemzés középpontjában az „információs társadalom” és a „digitális megosztottság” kifejezések meglehetôsen széles értelmezési tartománya áll. Az értelmezés céljára kiemeljük azokat a vonásokat és értékeket, amelyeket a legtöbbször társítanak ezekhez a kifejezésekhez.

A WSIS-dokumentumok tanulmányozása azért fontos, mert a konferencia átfogó „vízióját” és elvi irányvonalait tükrözik. A „vízióra” helyezett hangsúly ugyanakkor mind az Elvi nyilatkozatot, mind a Cselekvési tervet gyakran mindent felöleló jellegúvé és igen általánossá teszi (Klein, 2003). Ezek a dokumentumok azonban általános jellegük dacára is formálhatják a stratégiával kapcsolatos diskurzust, mivel a csúcstalálkozókon elfogadott dokumentumok általában befolyásolni tudják a stratégiai vitákat azáltal, hogy új kifejezések használatát vezetik be(Klein, 2003). A dokumentumokban foglalt javaslatok, szempontok és értékek elemzése - ezeket a tényeket szem elött tartva - döntô fontosságú lehet a lehetséges stratégiai következmények kimutatásakor. A tartalomelemzés különösen azt vizsgálja, hogy a WSIS-dokumentumok hogyan határozzák meg a fogalmakat, és hogyan befolyásolják az információs társadalomról és a globális digitális megosztottságról folyó vitákat. Ezek a viták potenciálisan erốteljes hatást gyakorolhatnak az említett kérdésekkel kapcsolatos globális gondolkodás alakulására.

A csúcstalálkozó két fơ dokumentumának tartalomelemzése megvilágítja a csúcstalálkozó elôírásait a digitális megosztottság kezelésére vonatkozóan. A tartalomelemzés célja az, hogy kritikailag vizsgálja azokat a szempontokat, javaslatokat és megoldásokat, amelyeket a WSIS ajánl a digitális megosztottság kezelésére. Az elemzéshez hozzátartozik a két fơ dokumentumban közzétett szöveg, az irányvétel, az értékek és a célok áttekintése.

A tartalomelemzés arra szolgál, hogy a kutatásban felvetett kérdéseket következetes és szisztematikus módon megválaszolja. Két részre oszlik: az első rész az Elvi nyilatkozattal, a második rész pedig a Cselekvési tervvel foglalkozik. Az Elvi nyilatkozat elemzésének középpontjában az információs társadalommal kapcsolatban az ENSZ és az ITU által elfogadott értékek, célok és „víziók” azonosítása áll. Ennek az elemzésnek a nagyobb része az „információs társadalom” és a „digitális megosztottság” kifejezések használatát vizsgálja az Elvi nyilatkozatban. Az, ahogyan ezeket a fogalmakat meghatározzák, igen fontos a WSIS szempontjainak és értékfelfogásának elemzéséhez. A nyelv az elfogultságok, a nézőpontok és értékek hatékony mutatója.

A Cselekvési terv elemzése a tervbe vett akciókra és azok megvalósításának vizsgálatára koncentrál. Pontosabban, a vizsgálat tárgyát egyrészt a gyakorlati megvalósítás során ténylegesen végrehajtott tevékenység, másrészt maguk a javaslatok képezik. Az elemzés alapját a WSIS Elvi nyilatkozata és Cselekvési terve alkotja. Ezek az írásos nyilatkozatok azért fontosak, mivel a csúcstalálkozó fóbb kézzelfogható eredményei közé tartoznak, amelyek a világközösség szemében meghatározzák az ENSZ-nek az információs társadalommal kapcsolatban elfogadott céljait, irányelveit, alapelveit és vízióját. A Cselekvési terv (Plan of Action, POA) alapja az Elvi nyilatkozat (Declaration of Principles, DOP), az a dokumentum, amely az információs társadalom közösen elfogadott értékeit fejti ki. Míg az Elvi nyilatkozat a WSIS általános irányelveit foglalja magában, a Cselekvési terv célja ezeknek az elveknek a gyakorlatba való átültetése. 
Az elemzés középpontjában az a fő kérdés áll, hogy a WSIS milyen álláspontot foglal el az információs társadalomról folyó vitában, hogyan közelíti meg a „digitális megosztottság" problémáját, és hogyan segíti elő az említett értékek érvényesülését és a javaslatok gyakorlati megvalósítását. A tartalomelemzés célja azoknak a szempontoknak, javaslatoknak és megoldásoknak a kritikai vizsgálata, amelyeket a WSIS ajánl a digitális megosztottság kezeléséhez. Az elemzéshez hozzátartozik a két fő dokumentumban közzétett szöveg, az irányvétel, az értékek és a célok áttekintése.*

\section{Az Elvi nyilatkozat tartalomelemzése}

Az elemzés kategóriái:

- Az „információs társadalom” kifejezés használata

○ A használat gyakorisága.

o Mire utal a kifejezés?/Hogyan határozzák meg a fogalmat?

o A fogalom leírásában használt melléknevek, a kifejezéssel összefüggésben leggyakrabban elóforduló szavak.

○ Ki határozza meg a kifejezés tartalmát?

- Hangnem/értékek

- A „digitális megosztottság” kifejezés használata.

\section{A Cselekvési terv tartalomelemzése}

Az elemzés kategóriái:

- Tevékenység

- Gyakorlati megvalósítás

\section{Eredmények és diszkusszió}

Mivel az „információs társadalom” kifejezés szerepel a csúcstalálkozó megnevezésében, nem meglepố, hogy ez a kifejezés gyakran elófordul az Elvi nyilatkozatban is. Elemzésünk szempontjából azonban az az érdekes, hogy a dokumentum hogyan határozza meg ezt a fogalmat, és milyen jelzôket, illetve milyen átfogó és részcélokat társít legtöbbször hozzá. Maga az „információs társadalom” kifejezés hatvanháromszor fordul elő az Elvi nyilatkozatban. Ennek a kifejezésnek a dokumentum átfogó témája szempontjából való fontosságát kiemeli, hogy szerepel a dokumentum alcímében, valamint mind a három fejezet címében is. A kifejezés szerepel továbbá a dokumentumot alkotó hatvanhét bekezdés - valójában hatvanhét „mininyilatkozat” közül negyvennégyben.

* Ez a mondat az eredeti angol nyelvứ tanulmányban kétszer szerepel. - $A$ ford. 
Az „információs társadalom” kifejezés eredetének magyarázata sehol sincs megadva a dokumentumban. Feltételezik, hogy az olvasó már tisztában van e fogalom jelentésével és a modern világ szempontjából való fontosságával. A kifejezés legpontosabb meghatározása a dokumentum első bekezdésében található: „Mi, a világ népeinek képviselói [...] kinyilvánítjuk közös vágyunkat és elkötelezettségünket az iránt, hogy felépítsünk egy emberközpontú, mindenkit felölelố és fejlődésre orientált információs társadalmat, ahol mindenki osztozhat az információ és a tudás létrehozásában, elérésében és hasznosításában, s ami lehetővé teszi az egyének, a közösségek és a népek számára, hogy fenntartható fejlődésük elősegítése és életminôségük javítása terén teljes mértékben valóra válthassák lehetốségeiket.” Úgy túnik tehát, hogy az „információs társadalomról” a WSIS által adott meghatározás a tudás és az információ közös tulajdonbavételének a fejlődési célok elérését szem elôtt tartó eszméjén alapul.

A kifejezésnek ezt a meglehetôsen pontatlan definícióját „a világ képviselői” fogalmazták meg. Ezek a képviselók ténylegesen bizonyos kormányok képviselôii, akik részt vettek a dokumentumok megfogalmazásának folyamatában. Szerzói státusukat mutatja a „mi” és a „mienk” névmások használata a szóban forgó „információs társadalommal” kapcsolatban. Például a dokumentum „Közös víziónk az információs társadalomról” alcímet viselő fejezetében szereplố tizennyolc állítás közül tizenhét tartalmazza a „mi” vagy a „mienk” szót, félkövér betútípussal szedve. Mivel a dokumentumok megfogalmazásának felelôsségét fóként kormányok képviselói viselik, a „mi” szó mindenkit felölelő konnotációja a dokumentumban vitatható. Továbbá, a „közös” szót a WSIS víziójának és céljainak leírására használják. Ennek a szónak a használata olyan értékeket sugall, amelyeket a világ valamennyi népe magáénak vall. Az olyan kifejezések használata, mint például a „közös vízió” és a „mindenkit felölelő [...] információs társadalom" arra szolgál, hogy az információs társadalomról szóló vitát új irányba terelje. Az „információs társadalom” természetére vonatkozó vita háttérbe szorul és elfojtódik a nemzetközi közösségben, ha ehhez hasonló átfogó és deklaratív kifejezéseket használunk. Az információs társadalomnak ezt a „közös vízióját” illetốen felmerülő bármilyen nézeteltérés feltehetôen kirekeszti a más véleményen levôket a nemzetközi közösség megszentelt terének birodalmából. Úgy túnik tehát, hogy az ENSZ és a világközösség hivatalos álláspontja az információs és kommunikációs technológiáknak a fejlődés eszközeiként való szúk és egyoldalúan pozitív felfogása. A technológiai utópizmust és determinizmust, ami áthatja az ENSZ-nek az információs társadalomról kialakított felfogását, a késóbbiekben az Elvi nyilatkozatban foglaltak tényleges cselekvéssé váltása, a gyakorlati megvalósítás természetének elemzésekor részletesebben tárgyaljuk.

$\mathrm{Az}$ „információs társadalom” leírásához használt jelzók mint kulcsszavak elemzése bepillantást nyújt a WSIS szemléletmódjába és értékfelfogásába. Az Elvi nyilatkozat első bekezdése „emberközpontú, mindenkit felölelố és fejlődésre orientált információs társadalom” leírását tartalmazza. A „mindenkit felöleló” jelzố további kilenc alkalommal fordul elő az „információs társadalom” leírásában. Az „emberközpontú” kifejezés még kétszer szerepel, ugyancsak az „információs társadalom” jelzôjeként. Ennek a két szónak a fő funkciója az „információs társadalom” kifejezés tartalmának pontosítása. Az információs társadalomnak - ahogyan a WSIS meghatározza - „mindenkit felölelônek” kell lennie, és az „emberek” szükségleteit kell kielégítenie. Ám mit ért vajon a WSIS a „mindenkit felöleló” szó alatt, ha a dokumentumok megfogalmazásában a kormányok 
képviselói játszották a fố szerepet? Továbbá, ami azt illeti, mit jelent az „emberközpontú" kifejezés? Honnan tudhatjuk, hogy az IK'T fejlesztési programok a fejlődô világban mikor emberközpontúak és mikor nem?

$\mathrm{Az}$ „információs társadalom” kifejezés tartalmának „aktív” jellemzésére a pontosító jelzók mellett különféle igéket is alkalmaznak. Ha megfigyeljük, hogy mely igék fordulnak elő a kifejezéssel kapcsolatban, ez további eligazítást ad az információs társadalom „helyzetével” és „állapotával” kapcsolatban. Az összes eset közül, ahol az „információs társadalom” említése szerepel, tizenkét alkalommal az „épít" vagy az „építés” szavak társulnak a kifejezéshez. Az „információs társadalomra” utalva négy esetben használják a „fejlódés” szót. Az „épít”, az „építés” és a „fejlódés” vagy „fejlesztés” szavak használata azt sugallja, hogy az információs társadalom még kváziképlékeny állapotban van, vagyis még nem alakult ki teljesen. A WSIS által leírt „információs társadalom” jellege és „állapota” következményekkel jár arra nézve, hogy az Elvi nyilatkozatban megfogalmazott víziót hogyan kell vagy hogyan lehet valóra váltani. Úgy túnik tehát, hogy máris információs társadalomban élünk, ám ugyanakkor építjük is azt. Az információs társadalom effajta, dinamikus folyamatra utaló víziója összhangban áll a kifejezésról adott munkadefinícióval. Az így felfogott információs társadalom középpontjában a „fejlốdés” áll. Továbbá, ezt a fajta társadalmat valamennyi kormány „közös víziója” határozza meg, és nem világos, hogy az információs társadalom ilyen meghatározása a kritikával és a vitákkal szembesülve mennyiben bizonyul majd rugalmasnak.

Összefüggésben azzal, ahogyan a WSIS megnevezi az „információs társadalmat", az Elvi Nyilatkozat végén elókerül egy olyan kifejezés is, ami korábban nem szerepelt, de kihatással van az egész dokumentumra. A dokumentum utolsó mondata így szól: „Bízunk abban, hogy ezek az intézkedések megnyitják az utat a valódi tudástársadalom jövóbeli fejlődéséhez.” A kulcskérdés itt a következô: Mi a „tudástársadalom”? Miben különbözik a tudástársadalom az információs társadalomtól? Az Elvi nyilatkozat erre nem ad semmiféle választ. Van-e valamilyen utalás arra, hogy a „tudástársadalom" valamiféleképpen jobb, mint az „,információs társadalom”? Ennek a kifejezésnek az implikációit az olvasó maga döntheti el. Figyelembe véve, hogy a „tudástársadalom” kifejezés az „információs társadalom” alternatívájaként a civil társadalmi szervezetek javaslatára került be a szövegbe, úgy túnik, hogy a civil társadalom felól.érkezố hangok bizonyos hatást gyakoroltak az Elvi nyilatkozatra. Ennek a kifejezésnek a hozzáadása azonban tartalmának világos tisztázása nélkül - csupán arra szolgál, hogy zavarossá tegye a dokumentum mondanivalóját.

Az elemzés következő részében az „információs társadalom” kifejezéshez társított értékekkel és az „információs társadalom” bizonyos intézményekhez és társadalmi csoportokhoz fúződő kapcsolataival foglalkozunk. Az alábbi elemzés kimerítóen felsorolja azokat a fontos értékeket, ügyeket és elveket, valamint az egyes ügyekben érintett csoportokat is, amelyeket az Elvi nyilatkozat az „információs társadalom” kifejezéshez társít. Az „információs társadalom” kulcsösszetevőiként a következő értékek jelennek meg:

1. kommunikáció;

2. emberi méltóság;

3. a tudomány központi szerepe;

4. a nók egyenjogú státusának biztosítása; 
5. a peremre szorult és sérülékeny társadalmi csoportok (ideértve a bevándorlókat, az egyes társadalmakon belül hontalanná vált személyeket és menekülteket, a munkanélkülieket és a hátrányos helyzetû́ vagy jogfosztott embereket, a kisebbségeket és a nomád csoportokat);

6. a bennszülött népek örökségének és kulturális hagyományainak megốrzése;

7. az IKT-infrastruktúrához, az információhoz és a tudáshoz való hozzáférés javítása, a képességek fejlesztése, az IKT-eszközök használatához szükséges készségek fejlesztése, ösztönző és lehetőségeket biztosító környezet teremtése minden szinten, az IKT alkalmazásainak fejlesztése és bôvítése, a kulturális sokféleség tiszteletben tartása és elôsegítése, a média szerepének elismerése, az információs társadalom erkölcsi dimenzióinak figyelembevétele, továbbá a nemzetközi és regionális együttmúködés ösztönzése;

8. szerep biztosítása az ENSZ, a kormányok, az üzleti szektor és a civil társadalom számára egyaránt;

9. összekötöttség;

10. univerzális, mindenütt biztosított, igazságos és ténylegesen megvalósítható hozzáférés az IKT-infrastruktúrához és szolgáltatásokhoz;

11. a postahivatalok, iskolák, könyvtárak és archívumok felhasználása az IKT-infrastruktúrához való nyilvános hozzáférési pontok kialakítására;

12. gazdag közélet;

13. mindenki számára biztosított képesség az információkhoz, az eszmékhez és a tudáshoz való hozzáférésre és azok továbbadására;

14. mindenki számára megfizethetố szoftverek biztosítása;

15. az analfabetizmus felszámolása és univerzális elemi oktatás;

16. partneri viszonyok a fejlett és a fejlődó országok között;

17. fokozott képességfejlesztés az oktatás, a technológiai know-how és az információhoz való hozzáférés terén;

18. az információ biztonsága, hálózati biztonság, bizalom;

19. lehetôségekben gazdag környezet;

20. törvényes rend, a versenyt támogató és technológiai szempontból semleges politika és szabályozórendszer;

21. kellő alapok a gazdasági növekedéshez;

22. a szellemi tulajdon védelme;

23. szabványosítás;

24. a nemzetközi jog tiszteletben tartása,

25. az internet mint központi fontosságú eszköz nemzetközi menedzselése,

26. a kulturális identitás, a kulturális és nyelvi sokféleség, valamint a hagyományok és a vallások tiszteletben tartása, a dialógus elôsegítése;

27. elsốrendú prioritás biztosítása a különféle nyelveken és formátumokban megjelenô tartalmak létrehozásának, elosztásának és megôrzésének;

28. a kulturális örökség megőrzése;

29. a sajtó és az információ szabadsága;

30. a béke tisztelete és a szabadság, az egyenlôség, a szolidaritás, a tolerancia, a közös felelősség és a természet iránti tisztelet értékeinek fenntartása; 
31. az igazságosság, az emberi méltóság és az emberi lények nagy becsben tartását elôsegítố erkölcsök;

32. az IKT-eszközök illegális használatának és a velük való visszaéléseknek a megakadályozása;

33. eredendốen globális szemlélet;

34. regionális integráció;

35. az ITU mint központi szervezet kompetenciájának fenntartása;

36. kooperáció;

37. utómunkálatok és további elốrehaladás a digitális szakadék** áthidalása terén;

38. a globális szolidaritáson, valamint a népek és nemzetek közötti jobb kölcsönös megértésen alapuló közös tudás.

Ez a felsorolás érzékelteti a WSIS nagyra törố céljait és ambícióit. Úgy túnik, hogy a program mindenre és mindenkire kiterjed. Az információs társadalom ilyen óriási vízióját, amely célba veszi a marginalizálódott helyzetú csoportok szükségleteit és ugyanakkor az internet menedzselésével is foglalkozik, szinte túlságosan nehéz értelmezni. A dokumentumban megjelenô számos elv és érték igazolása olyan-az ENSZ-tól és más forrásokból származó - deklarációkban található meg, mint például az Emberi Jogok Egyetemes Nyilatkozata (Universal Declaration of Human Rights). Ez az önhivatkozási módszer az ENSZ és más szervezetek csúcstalálkozóira és programjaira való utalásokkal igazolja a WSIS által az „információs társadalomról” alkotott kép mindent átfogó jellegét. Valójában azonban a WSIS - ahogy céljai és elvei egyre diffúzabbá és „univerzálisabbá" válnak - veszít erejéból.

Elemzésünk szerint a dokumentum azt sugallja, hogy az információs társadalom beköszöntése alapvetóen az információs és kommunikációs technológiáknak, illetve azok használatának és alkalmazásainak köszönhetố. Már maga ez a tény is lényegében a technológiai determinizmus „ízét” kölcsönzi a WSIS állásfoglalásainak. Például az „IKT” rövidítés negyvenkilenc alkalommal fordul elő az Elvi nyilatkozatban, és a hatvanhét bekezdés közül harmincban szerepel. Így tehát a megfogalmazott elveknek majdnem a fele vagy az IKT-re, vagy az IKT alapú alkalmazásokra koncentrál. A méltányosság kedvéért azonban hozzá kell tennünk ehhez, hogy az Elvi nyilatkozat az IKT-tól függetlenül is megemlít olyan fontos értékeket, mint a tudás megosztása és hasznosítása. Az uralkodó téma és érték azonban mégiscsak az IKT, ami eszközként szolgál az ENSZ által vizionált utópia eléréséhez. A dokumentum fó fókuszában az információs és kommunikációs technológiák állnak, valamint az a kérdés, hogy ezek hogyan tehetik jobbá a társadalmat. Az „információs társadalom” a WSIS felfogásában alapvetően a technológia szerepén nyugszik.

A „digitális megosztottság” kifejezés csupán öt alkalommal fordul elố az Elvi nyilatkozatban, ellentétben az „információs társadalom” kifejezés igen gyakori használatá-

\footnotetext{
** Az eredeti tanulmányban mindenütt a digital divide kifejezés szerepel, ami szó szerint „digitális vízválasztót” jelent. Ennek megfelelójeként a magyar szakirodalomban az utóbbi években a fogalom tartalmát árnyaltabban és pontosabban visszaadó „digitális megosztottság” kifejezés használata terjedt el, a korábban megszokott és egyes szerzók által ma is használt „digitális szakadék” helyett. E tanulmány fordításában ezért legtöbbször a „digitális megosztottság” kifejezést használom, de azokban az esetekben, ahol ez az „áthidalás” (bridging) szóval együtt fordul elô, megfelelóbbnek látszik „digitális szakadékról” beszélni. - A ford.
} 
val. Az elóbbi kifejezés használatának hiánya meglepó, az információs társadalommal kapcsolatos vitára való kizárólagos koncentrálás figyelembevételével azonban ez a hiány érthetố. Maga a „digitális megosztottság” kifejezés önmagában is problematikus, mivel nem kétértékú, hanem sokrétú problémára utal - a WSIS-dokumentumok megfogalmazói talán maguk is éppen ezért kerülték a használatát. A dokumentumok közelebbi vizsgálata alapján azonban kitúnik, hogy nem ez az ok, mivel mégis a kérdés kétértékú megközelítését választják.

A digitális megosztottság elsố említésére a tizedik bekezdésben bukkanhatunk rá a következő megállapításban: ,teljes mértékben elkötelezettek vagyunk amellett, hogy ezt a digitális megosztottságot digitális lehetôségekké változtassuk mindenki számára, különösen azoknak az esetében, akikre a lemaradás és a további marginalizálódás veszélye leselkedik". Ezt a tizedik bekezdésben szereplố mondatot megelőzóen a digitális megosztottság olyan meghatározása található, miszerint az elsốsorban azt a helyzetet jelenti, amelyben „az információs technológiai forradalom elônyei és jótéteményei ma egyenlótlenül oszlanak meg a fejlett és a fejloodố országok között, és az egyes társadalmakon belül". Ez a jelenség elfogadható értelmezésének túnik, mivel a hangsúly itt a technológiák jótéteményeire esik, nem pedig a technológiák puszta meglétére. A szóban forgó mondat egy sajátságos része azonban a „digitális lehetôségek” kifejezést tartalmazza. Valóban, ez a bizonyos kifejezés mindkét dokumentum más részeiben is megjelenik. Pontosan mi is tehát a digitális lehetôség? Az ember arra a feltételezésre hajlik, hogy ez pozitívum lehet, azonban - meghatározás nélkül hagyva - puszta klisének hangzik. A ,digitális megosztottság” vagy "digitális szakadék” második említésével a tizenhetedik bekezdésben találkozunk, ahol az a megállapítás szerepel, hogy „az információs társadalom céljai közé tartozik a digitális szakadék áthidalása, és a harmonikus, méltányos és igazságos fejlődés biztosítása mindenki számára”.

A digitális megosztottság harmadik említése a hatvanegyedik bekezdésben szerepel: „Meg vagyunk gyoózódve arról, hogy világszerte elfogadott cél a digitális szakadék áthidalásához való hozzájárulás, az IKT-eszközökhöz való hozzáférés elősegítése, a digitális lehetôségek megteremtése és az IKT által a fejlôdéshez nyújtott lehetôségek kihasználása”. Itt ismét a „digitális lehetôségek” említésével találkozunk, és ebben az esetben is az „áthidalni” ige már ismerôs használata utal a digitális megosztottság legyőzésének módjára. A digitális megosztottság negyedik előfordulása a hatvannegyedik bekezdésben található, ahol említés történik a Nemzetközi Távközlési Unió (International Telecommunication Union, ITU) fontosságáról - megint csak , a digitális szakadék áthidalásában”. A digitális megosztottság vagy szakadék ötödik említésekor a hatvanhatodik bekezdésben szintén szerepel az „áthidalás” (bridging) szó. Az „áthidalni” ige egyike a digitális megosztottsággal kapcsolatban jelenleg leggyakrabban használt népszerú kifejezéseknek. Az „áthidalás” feltételezi valamilyen szakadék vagy rés, hasadék létezését, továbbá a „lezárás”, a „befejezés” (closing) aktusára vagy folyamatára utal. A mi munkadefiníciónk értelmében a digitális szakadék vagy megosztottság „lezárásának” gondolata megfelelő lehet, ha magában foglalja a társadalmi inklúzió és az igazságosság eszméit. Az, hogy a WSIS pontosan hogyan értelmezi ,a digitális szakadék áthidalását”, elemzésünk során jobban láthatóvá válik késóbb, amikor a Cselekvési tervben megfogalmazott tevékenységek természetével foglalkozunk. Általában azonban úgy túnik, hogy az Elvi nyilatkozatból hiányzik a digitális 
megosztottság világos meghatározása, és az inkább kétértékú, mintsem sokoldalú problémaként jelenik meg.

Miután megvizsgáltuk az „információs társadalom” és a „digitális megosztottság” kifejezések használatát az Elvi nyilatkozatban, elemzésünkben most áttérünk az értékek, a célok és a tevékenységek részletesebb vizsgálatára. Ezt az elemzést kiterjesztjük a Cselekvési tervre is, mivel hasznos lehet, hogy az Elvi nyilatkozatban foglalt „,elvekkel” összevetve lássuk a dokumentumban javasolt gyakorlati megvalósítás természetét.

A Cselekvési terv bevezetésétól kezdve azt látjuk, hogy a dokumentum célja az elvi nyilatkozatban foglalt „közös vízió” lefordítása „konkrét cselekvési programmá a nemzetközileg elfogadott célok, köztük a Millenniumi Deklarációban, a Monterrey Konszenzusban, valamint a Johannesburgi Deklarációban és Cselekvési Programban megfogalmazott célok teljesítésének elősegítésére”.**** Ezeket a célokat „az IKT-alapú termékek, hálózatok, szolgáltatások és alkalmazások használatának elôsegítése, valamint a digitális megosztottság legyốzéséhez egyes országoknak nyújtott segítség útján" látják elérhetốnek. Így tehát a dokumentum elsố bekezdésétól fogva azt látjuk, hogy az IKT-eszközöknek a digitális megosztottság „legyốzésére” való felhasználásával kapcsolatos elgondolásokat a technológiai determinizmus hatja át. A digitális megosztottság ilyen felfogása nem dialektikus jellegú, nem támaszkodik szélesebb társadalmi-kulturális kontextusokra, és ugyanannak a kettős struktúrának a hibájában szenved, amely a tárgyról folyó viták többségét jellemzi. Azt sugallja, hogy egyszerúen a technológia rendelkezésre állása meg fogja oldani a problémát. A bevezetés következố bekezdésében található az „információs társadalom” eddigi legteljesebb meghatározása, miszerint az „kifejlődóben levố fogalom, amely a fejlődés különböző szakaszait tükrözve különféle szinteket ért el szerte a világon". Noha ez a kifejezés folyamatra orientált értelmezéséról tanúskodik, továbbra is kérdéses marad, hogy mit jelentenek a „fejlődés” különböző szakaszai, és hogyan mérhetô, hogy az egyes országok milyen „szinteken” állnak az információs társadalom tekintetében. Az IKT gyakorlati használatbavétele terén vajon minden ország a fejlett világ „szintjére” fejlődik? El kell tûnődnünk azon, hogy e mögött a deklaráció mögött milyen inherens feltételezések állnak.

A Cselekvési terv bevezetésének utolsó része azoknak a szerepét írja le, akik az információs társadalomban , a téteket tartják”. A kormányok vezetố szerepet játszanak az „elóremutató és fenntartható e-stratégiák” kidolgozásában. A magánszektor fontos „az IKT fejlesztésében és terjesztésében”, de a dokumentum megemlíti , a fenntartható fejlődés szélesebb kontextusában" játszott szerepét is. A téteket tartó harmadik csoport, a civil társadalom „egyenlố fontosságú az egyenlôségelvú információs társadalom megteremtésében, és a fejlődés IKT-vel összefüggố kezdeményezéseinek megvalósításában”. Az utolsó csoportot alkotó „nemzetközi és regionális intézmények, valamint a

*** A 2000-ben tartott Világélelmezési Csúcstalálkozón elfogadott Millenniumi Deklaráció, amelyet a világ összes országa aláírt, többek között azt tûzte ki célul, hogy 2015-ig a világ éhezóinek számát a felére, az 5 éven aluli gyermekek halandóságát pedig egyharmadára kell csökkenteni. Az ENSZ égisze alatt tetô alá hozott, 2002 márciusában a mexikói Monterreyben 171 ország által aláírt ún. Monterrey Konszenzus a szegénység 50 százalékos csökkentését jelölte meg 2015-re elérendô célként. A szintén 2002-ben Johannesburgban rendezett második „Föld Csúcs”, a Fenntartható Fejlődés Világkonferenciája alkalmából elfogadott cselekvési terv külön fejezetben foglalkozik a víz- és szennyvízhigiéné, az egészségügy, a mezôgazdaság, az energia és a biodiverzitás problémáival, valamint a fenntartható fejlődés intézmény-és eszközrendszerével. - $A$ ford. 
nemzetközi pénzügyi intézmények kulcsszerepet játszanak az IKT felhasználásának a fejlódési folyamatba való integrálásában és az információs társadalom felépítéséhez, valamint a megtett haladás értékeléséhez szükséges források elérhetôvé tételében". A bevezetésnek ez az utolsó bekezdése talán a dokumentum legfontosabb része, mivel ez fogalmazza meg a Cselekvési terv végrehajtásához szükséges tevékenység természetét. A dokumentum - a téteket tartó szereplóknek ezeket a csoportjait felsorolva - számba veszi az összes lehetséges alapot, olyan mértékben próbálva „mindent felölelni”, amennyire az csak lehetséges. A kormányok szerepet játszanak az „e-stratégiákban” íme egy sikamlós új szó az IKT-vel összefüggố tervezésre. Érdekes megfigyelni, hogy a magánszektort mint a fenntartható fejlôdés letéteményesét említik. Nem világos, hogy ez a tény mit von maga után. Az internet fokozódó kommercializálódása kétségtelen tény a fejlett világ nagy részében, ám az még nem dólt el, hogy ezen a téren mi fog történni a fejlődő világban. Úgy túnik azonban, hogy ennek az állításnak a beillesztésével az ENSZ mintegy támogatását nyújtja a tartalomszolgáltatás, az infrastruktúra és a hozzáférési eszközrendszer szélesebb körú privatizációjához és az üzleti szereplốk által történố ellenốrzéséhez a fejlôdố világban is. Ezek az akciók vegyes következményekkel járhatnak a hozzáférési lehetóségekre nézve, és csak az idő fogja megmondani, hogy a nagyobb mértékú privatizáció jobb vagy rosszabb hozzáférést fog-e eredményezni. Ez az állítás ugyanakkor egyértelmúen jelzi, hogy a nemzetközi közösség vonakodik a beavatkozástól, és képtelen szembenézni a privatizáció és a szellemi tulajdonjogok kérdéseivel, amelyek pedig az igazságossággal kapcsolatos problémák középpontjában állnak az információs társadalomban.

Annak az említése, hogy a civil társadalom partnerként vesz részt az információs társadalom felépítésében, arra irányuló kísérlet, hogy az információs társadalom kiépítése során a nem kormányzati szervezetek (Non Governmental Organizations, NGOs) jelentôs kontingensét is bevonják az igazságosság és a hozzáférés kérdéseinek kimunkálásába. A „civil társadalom” az $N G O$-k hangját képviseli, amelyek feltehetően az „egyszerú emberek" nevében lépnek fel. A civil társadalom partnerként való egyszerú megemlítése azonban nem bizonyult elegendốnek a WSIS-étól eltérố nézeteket hirdetố civil társadalmi hangok elnyomására. Az alulról jövó mozgalmak gyanakvással és bizalmatlansággal fogadják, hogy a WSIS felfogása az információs társadalomról túlságosan szúk, technológia-központú, és nem fektet elegendố hangsúlyt az emberi szükségletekre. A WSIS-hez alternatívát nyújtó Civil társadalmi nyilatkozat (Civil Society Declaration) megfogalmaz néhányat ezek közül az aggodalmak közül.****

Az említett szereplók utolsó csoportja talán a legfontosabb a fejlődó világ szempontjából, mivel az a gyakorlati megvalósítás lényegi kérdéseiben érintett. A „nemzetközi pénzügyi intézmények" említése valójában eufemizmus, ami valójában csak a fejlesztés terén múködő két fóbb pénzügyi intézményre, a Világbankra és a Nemzetközi Valutaalapra (International Monetary Fund, IMF) utal. Ezek az intézmények vitatott szerepet játszanak, elsősorban a már végrehajtott „strukturális kiigazítási” programjaik következtében, amelyek vegyes, néha káros hatással voltak a fejlődő országokra. Az „információs társadalom" megteremtésére irányuló tervek gyakorlati megvalósításának fố eszköze a fejlődố világban minden bizonnyal ez a két pénzügyi intézmény lehet.

**** Lásd www.smsitunis2005.org/plateforme/pdf/civil-society-declaration-en.pdf. - A ford. 
Az általános és a szúkebb célokkal és feladatokkal foglalkozó következố fejezet (Objectives, goals and targets) kifejti a cselekvési terv céljait, és megemlíti, hogy ,a WSIS második fázisában alkalom fog nyílni a digitális szakadék áthidalása irányában tett elôrehaladás mérlegelésére és értékelésére". Nem világos azonban, hogy ez a mérlegelés és értékelés hogyan fog történni. Továbbá nem ismeretes, hogy a siker méréséhez milyen eszközöket és milyen kritériumokat fognak alkalmazni. A gyakorlati megvalósítást illetően a dokumentumban az szerepel, hogy „az információs társadalom építésének konkrét célfeladatait" - a szükségleteknek megfelelően - az országok kormányai fogják kidolgozni a nemzeti e-stratégiák kontextusában. Az értékelésról tehát a nemzeti kormányok dönthetnek.

A Cselekvési tervben megfogalmazott legambiciózusabb célok némelyike konkrét akciókat irányoz elố a 2015. évig. A 2015. év kiválasztása sajátságos vonás - az ENSZ által finanszírozott más programok - például az „Oktatás mindenkinek” (Education for $A l l, E F A)$ elnevezésú kezdeményezés - szintén a 2015. évet jelölik meg „mágikus határidóként”. Egy példát említve, az ilyen ambiciózus célok egyike szerint „biztosítani kell, hogy a világ lakosainak több mint a fele hozzájusson az IKT-eszközökhöz”. Ez kétségkívül csodálatra méltó cél, de nem tartalmaz semmiféle követelményt sem a tartalom minôségére, sem pedig a technológiák természetére vagy potenciális használati értékére vonatkozóan. A dokumentum nyelvezete ismét csak a technológiai determinizmus értékeit támogatja. A figyelem középpontjában az emberek IKT-eszközökkel való „összekötöttsége” áll, mintha a digitális megosztottsággal való szembenézés egyetlen problémája egyszerúen az lenne, hogy a technológiát eljuttassuk az emberekhez. A WSIS védelmében meg kell jegyeznünk, hogy ezeket a célokat általánosnak szánják, és a konkrét egyedi megoldásokat a nemzeti kormányokra bízzák. Elemzésünk következố részében néhány konkrétabban megfogalmazott gyakorlati megvalósítási javaslattal foglalkozunk. Úgy tûnik azonban, hogy jórészt ugyanaz a technológiai determinista gondolkodás hatja át a dokumentum többi részét is.

A kormányok szerepéról szólva a fejlő́dés szolgálatába állított IKT tekintetében a „nemzeti e-stratégiák” kidolgozását említi a dokumentum. Az „e-stratégia” kifejezés használata arra irányuló kísérletnek tekinthetô, hogy a vállalkozás az élvonalbeli korszerüség és a technológiai hozzáértés színezetét kapja. Elsố pillantásra azonban korántsem világos, hogy az e-stratégia valójában micsoda. Késóbb a Cselekvési terv megemlíti az IKT-nek az élet különféle területein való alkalmazásait: például az „e-kormányzat” és az „e-egészségügy” az „e-stratégiák” konkrét leképezései a való világra. Elemzésünk alapján arra a megállapításra jutottunk, hogy az „e-” elő́taggal ellátott kifejezések használata csupán az IKT és az általa a társadalmak számára nyújtott potenciális előnyök „fetisizálására” szolgál. Ezzel azonban nem azt akarjuk mondani, hogy a meglévő szakterületeknek az IKT felhasználásával történố átalakítására és fejlesztésére irányuló kísérlet rossz dolog, a kritika inkább a nyelvhasználatra vonatkozik, ami a technológiai determinista gondolkodást segíti elő és tartja fenn.

Az információs társadalom kiépítésében a nemzeti kormányok játszanak központi szerepet, mivel az információs társadalom felépítésére és az IKT fejlesztési célú használatára vonatkozó számos javaslat a nemzeti e-stratégiákra és nemzeti cselekvési tervekre támaszkodik. A gyakorlati megvalósításban érintett más fontos szereplóknek azonban „partnerkapcsolatokat” kell kiépíteniük egymással, hogy létrehozhassák az információs 
társadalmat A WSIS céljainak megvalósításához minden szinten szükség van továbbá a „nemzeti, regionális és nemzetközi együttmúködésre” is. Valamennyi résztvevő „,együttmúködése” fogja csak valóra váltani az utópisztikus „információs társadalom” álmát.

Noha az „információs társadalom” fontos szereplóit és az általuk betöltendő szerepek egyikét-másikát a dokumentum meghatározza, nem világos, hogy a „partnerkapcsolatok”, az „együttmúködés” és a „szolidaritás” hogyan fog megvalósulni. A WSIS mindezeket olyan keretrendszerben javasolja, amely nem eredeti, és valójában a nemzetközi konferenciák retorikájára és „kipróbáltan bevált” frázisaira támaszkodik. A gyakorlati megvalósítás felelôsségének nagy része a nemzeti kormányok vállán nyugszik, amelyeknek gyakran nincs túlságosan nagy késztetésük ennek a „víziónak” a megvalósítására, sốt hiányoznak az ehhez szükséges pénzügyi forrásaik is. Az egész vállalkozás a WSIS ,javaslatain” és „ajánlásain" nyugszik, semmi máson. Ez a tény egyébként nem meglepó, a WSIS-hez hasonló nemzetközi csúcstalálkozók nem azzal a céllal jönnek létre, hogy eleve beépített megvalósítási mechanizmusokat kínáljanak. A digitális megosztottság és az információhoz való hozzáférés javítása terén a fejlődó országokban jelentkezố problémák kezelését tekintve azonban úgy tû́nik, hogy a célok megvalósítása az „együttmúködés” és a „szolidaritás” ingatag eszméin nyugszik. A valóságban a fejlődő országok számára megfogalmazott fenti célok és javaslatok jó részének megvalósítása csakis a Világbankon és az $I M F$-en keresztül történhet, amelyek meglehetôsen vegyes múltbeli teljesítményt mutatnak fel, és nem örvendenek egyértelmú tiszteletnek. A cselekvési terv azt javasolja, hogy „a releváns nemzetközi szervezetek és pénzügyi intézmények”, például a Világbank és az $I M F$ „,dolgozzák ki saját stratégiáikat az IK'T felhasználására a fenntartható fejlődés érdekében”.

Mind az Elvi nyilatkozat, mind a Cselekvési terv megvizsgálása után itt az ideje annak, hogy elemzésünket az eredetileg feltett négy kutatási kérdésünkhöz visszatérve fejezzük be. Az elsó kérdésünk az volt, hogy a WSIS hogyan határozza meg az „információs társadalmat". Az erre adandó választ illetôen az elemzés azt mutatta ki, hogy a meghatározás - jellegét tekintve - nagymértékben pozitív előjelú volt, és az IKT, valamint annak a társadalomra gyakorolt hatása tekintetében utópisztikus felfogást fejezett ki. A WSIS csúcstalálkozót - természeténél fogva - nem az IKT elốnyeinek megkérdójelezésére hozták létre, hanem egy olyan program továbbvitele érdekében, ami az IKT-eszközöket mintegy inherens ,javaknak” tekinti a világban. Az utópisztikus perspektíva önmagában még nem szükségképpen negatív vonás. A WSIS keretében történố alkalmazása mindazonáltal problematikus, éppen az ENSZ legitimáló hatalma miatt, amely képes befolyásolni a világ közvéleményét egyes témákban. Az utópisztikus elgondolás a mai világban illuzórikus, azonban pozitív cél lehet, amelyért érdemes küzdeni. Ideálokra szükség van, és azokat nem szabad kárhoztatni, de az utópizmus a WSIS részéról nem konstruktív, mivel túlságosan leegyszerúsít és általánossá tesz egy versengéstôl áthatott vitát, s ennek jelentős politikai következményei lehetnek.

A WSIS az információs társadalmat „mindenkit felölelóként” és „fejlôdésre orientáltként" határozta meg. Az azonban nem egészen világos, hogy ezek a kifejezések mit jelentenek. Azáltal, hogy megnevezett értékeket tulajdonított az így értelmezett „,információs társadalomnak", az ENSZ egyfajta keretet hozott létre ennek a felfogásnak a terjesztéséhez az egész nemzetközi közösség körében.

A globális digitális megosztottság meghatározására vonatkozó második kutatási kérdésünket tekintve azt mondhatjuk, hogy a WSIS meghatározása bináris természetú 
maradt, és azt a felfogást tükrözte, miszerint pusztán a technológia elérhetôvé válása segíteni fog e probléma enyhítésében. A digitális megosztottság sokrétú jelenségként való felfogása nem található meg a WSIS-dokumentumokban. A kulturális sokféleség és a képességfejlesztés fontosságát az „információs társadalom” szempontjából általános megfogalmazásban megemlítik ugyan, de a „digitális megosztottság” meghatározása továbbra is a technológiai determinizmus felfogását tükrözi.

A harmadik kérdés, amely a megvalósítást szolgáló tevékenységek természetére vonatkozik, segített megérteni, hogy a WSIS hogyan kívánja valóra váltani vízióját. A dokumentumokban a következố négy csoport szerepel, amelyeknek együtt kell múködniük és közösen kell dolgozniuk: a nemzeti kormányok, a magánszektor, a civil társadalom, valamint a nemzetközi és regionális intézmények, ideértve a nemzetközi pénzügyi intézményeket is. Nincs azonban kifejtve, hogy ezek az elkülönült csoportok hogyan tanulhatnak meg együtt dolgozni, és az sem, hogy ezek a szereplók - különösen a nemzeti kormányok - hogyan tehetnek szert a célok megvalósításához szükséges eszközökre. Megemlítik a Digitális Szolidaritási Alapot mint az IKT fejlesztését segítô, önkéntes hozzájárulásokból származó pénzalapot, de ennek a a jövôje és potenciális hatásai bizonytalanok maradnak. A magánszektor szerepet kapott a „fejlesztésben”, ám csak ezután fog kiderülni, hogy ennek milyen hatása lesz a fejlődố országokra. A „nemzetközi pénzügyi intézményeket" a dokumentumok nem nevezik meg, de kétségkívül a Világbankról és az IMF-ról van szó. Ezeknek az intézményeknek a kezében igen nagy hatalom van a fejlődő országok befolyásolására, eddigi tevékenységük azonban vegyes eredményekkel járt. Egyelốre nem tudhatjuk, hogy az IKT fejlesztése hogyan fog történni ennek a két intézménynek az égisze alatt.

Végül a technológiai determinizmus szintjét firtató utolsó kérdésre az a válasz adható, hogy a WSIS dokumentumok visszhangzó módon megerósítik ezt a diszkreditált gondolkodásmódot. A túlzott mértékben az IKT-ra helyezett hangsúly, az „információs társadalom" kifejezés és az IKT egymással szoros összefüggésben való ismételt használata, továbbá a mindent átható pozitív hangnem, ami a technológiától várja az emberi problémák egész sorának megoldását - mindez a technológiai determinista gondolkodást tükrözi.

\section{Konklúzió}

Az ENSZ erófeszítései a WSIS finanszírozására, valamint az IKT fontosságának és a fejlődésben játszott potenciális szerepének nyomatékos hangsúlyozására valóban bámulatosak. Pozitívumként kell említeni, hogy az ENSZ segített ráirányítani a figyelmet egy olyan tárgyra, amely a mai világban egyre nagyobb fontosságra tesz szert. Egy olyan program létrehozására irányuló kísérlet, amely az IKT felhasználására koncentrál annak érdekében, hogy a világ népességének valamennyi szegmentumát, különösen a szegény és marginalizált népeket segítse, nemes vállalkozás. A genfi WSIS-csúcstalálkozó azonban - a jó szándékok és tiszteletre méltó erófeszítések dacára - az Elvi nyilatkozat és a Cselekvési terv formájában nem kielégítő örökséget hagyott maga után.

Érthetô, hogy a csúcstalálkozó dokumentumai igen nagy általánosításokat tartalmaznak, és csupán mintegy küldetésnyilatkozatként szolgálnak, a politikai erók tájé- 
koztatásának elősegítésére. Ennek elismerése mellett is tény marad azonban, hogy az „információs társadalomról” mind az Elvi nyilatkozat, mind a Cselekvési terv teljes mértékben utópisztikus képet fest, amely nagymértékben túlegyszerüsít és általánosít egy komplex kérdést és társadalmi jelenséget. A WSIS egy bonyolult kérdésról javában folyó vitában foglal állást, amikor még korántsem létezik egyértelmú konszenzus. A csúcstalálkozó víziója az „információs társadalomról” fóleg az IKT-n alapul, és megfogalmazásában technológiai determinizmus tükröződik. Általános egyetértés van abban, hogy az információs iparágak és az IKT fontos szerepet játszanak a mai világban, de a WSIS „információs társadalma” az IKT és általában a technológia „fetisizálását” szolgálja, elốsegítve a technológiai determinizmus, a leegyszerúsített válaszok, sốt, talán a rossz megoldások terjedését is. Úgy tưnik, hogy a konferencia elkövetkezố tuniszi fázisához vezetố út hasonló irányvonalat követ.

Ha csak egy pillantást vetünk mindkét dokumentumra, az a benyomásunk támad, hogy az IKT lehetőséget biztosít számos emberi probléma és szenvedés megszüntetésére. Aligha ez a valóságos helyzet, azonban ha az IKT-t valamely holisztikus stratégia részeként használják fel a szegénység enyhítésére, akkor már fontos lépés történik előre. A WSIS el is ismeri, hogy az IKT nem az egyetlen eszközrendszer a fejlődés szolgálatában, de az ,információs társadalom" meghatározásával azt a benyomást kelti, hogy az IKT - ha megfelelóen alkalmazzák - át fogja alakítani a világot, békét és gazdagságot hozva magával. Bárcsak ilyen egyszerú lenne!

Szélesebb filozófiai perspektívából tekintve megkérdójelezhetô, hogy az ENSZnek és a „világközösségnek” miféle felhatalmazása vagy jogosultsága van kinyilvánítani, hogy mindannyian ,információs társadalomban” élünk, és azt tovább kívánjuk építeni. Valójában még mindig vitatott, hogy vajon csakugyan ilyen fajta új társadalomban élünk-e vagy sem, és az így elnevezett társadalomtípus alapvetố természete sem tekinthetố tisztázottnak. Az ENSZ azonban már eldöntötte, hogy ez az „információs társadalom" milyen lesz, és a róla adott meghatározásának legitimitását azzal igazolja, hogy „közös vízióra” hivatkozik.

A WSIS tényleges hatásait a „digitális megosztottság” problémájának felfogására és kezelésére az fogja megmutatni, hogy a nemzeti kormányok, illetve a Világbank és az $I M F$ hogyan reagálnak a javaslatokra. A WSIS azáltal, hogy kidomborította az IKT-nek a fejlődésben játszott szerepét, pozitív lépést tett, de az információs társadalommal és a globális digitális megosztottsággal kapcsolatos vitákat a végletekig leegyszerúsítve, a technológiai determinizmus szellemében interpretálta, s ennek a jövóben negatív következményei lehetnek.

\section{Ajit K. Pyati}

Ajit K. Pyati a UCLA Informatikai Karának PhD-hallgatója. Érdeklődése középpontjában a modernizáció és az információ diskurzusai állnak. 


\section{Köszönetnyilvánítás}

E tanulmány nagyrészt a UCLA doktori kurzusán benyújtott disszertációm eredményeire épül. Hálás vagyok három kiváló bizottsági tag, Clara Chu, Leah Lievrouw és Doug Kellner segítségéért, iránymutatásáért és támogatásáért.

\section{Irodalom}

Bogdanowicz, Marc - Burgelman, Jean-Claude - Centeno, Clara - Gourova, Elisaveta - Carat, Gérard (2003): Factors of regional/national success in Information Society developments: Information Society strategies for candidate countries. First Monday, vol. 8, number 10 (October), at: http://www.firstmonday.org/issues/issue8_10/bogdanowicz/index.html, accessed 2 March 2004.

Cogburn, Derrick L. (2003): Governing global information and communications policy: Emergent regime formation and the impact on Africa. Telecommunications Policy, vol. 27, 135-153.

International Commission for the Study of Communication Problems (1980): Many voices, one world: Communication and society, today and tomorrow. Paris: UNESCO.

Kellner, Douglas (1990): From 1984 to One-Dimensional Man: Reflections on Orwell and Marcuse. Current Perspectives in Social Theory, 223-252, and

http://www.uta.edu/english/dab/illuminations/kell13.html and http://www.uta.edu/english/dab/illuminations/kell13.html.

Klein, Hans (2003): Understanding WSIS: An institutional analysis of the UN World Summit on the Information Society. Internet and Public Policy Project, School of Public Policy, Georgia Institute of Technology, at www.ip3.gatech.edu, accessed 15 February 2004.

Lievrouw, Leah - Bucy, Erik P. - Finn, T. Andrew - Frindte, Wolfgang - Gershon, Richard Haythornthwaite, Caroline - Kohler, Thomas - Michel Metz, J. - Sundar, S. Shyam (2000): Bridging the subdisciplines: An overview of communication and technology research. In Gudykunst, W. (ed.): Communication Yearbook. Vol. 24, 272-296.

MacLean, D. (2003): The quest for inclusive governance of global ICTs: Lessons from the ITU in the limits of national sovereignty. Information Technologies and International Development, vol. 1 , issue $1,1-18$.

Schement, Jorge - Lievrouw, Leah (1986): The fundamental assumptions of Information Society research. In Schement, Jorge - Lievrouw, Leah (eds.): Competing visions, complex realities: Social aspects of the Information Society. Norwood, N. J.: Ablex.

Shimmon, Ross (2004): Digital opportunity or flashy fizzle? The UN's World Summit on the Information Society. American Libraries, vol. 35, number 2, 24-25.

Webster, Frank (2002): Theories of the Information Society. New York: Routledge.

World Summit on the Information Society (2003): Declaration of Principles. Building the Information Society: A global challenge in the new millenium, at http://www.itu.int/wsis, accessed 12 January 2004.

World Summit on the Information Society (2003): Plan of action, at http://www.itu/int/wsis, accessed 12 January 2004. 


\section{A megjelenés előtörténete}

A kézirat 2005. március 27-én érkezett be és 2005. április 10-én fogadták el közlésre.

HTML markup: Kyleen Kenney and Edward J. Valauskas; Editor: Edward J. Valauskas

\section{Creative Commons Licence}

WSIS: Whose vision of an information society? by Ajit K. Pyati First Monday, vol. 10, number 5 (May 2005),

URL: http://firstmonday.org/issues/issue10_5/masum/index.html 